ORIGINAL ARTICLE

\title{
Scientific Hegemony in the higher education system: A critical review
}

\author{
SHAHRAM YAZDANI ${ }^{1}$, SOLEIMAN AHMADY ${ }^{2}$, ALIREZA SHAHRIARI ${ }^{3 *}$ \\ 1,2 Department of Medical Education, virtual School of Medical Education and Management, Shahid Beheshti University of Medical Sciences, \\ Tehran, Iran \\ ${ }^{3 *}$ Corresponding author: Alireza Shahriari, Ali3shahriari@yahoo.com
}

\begin{abstract}
Introduction and purpose: The scientific and technological Hegemony of Iran in the next fifty years is not a thematic plan with daydreaming and dreaming, but the depiction of a reality based on a vision document and with a firm determination of the people and officials of the country in the not-too-distant future for this border And the canvas will be created. The purpose of this study is to design a conceptual model of Scientific Hegemony in the higher education system by critical review.

Methods: This study was conducted as a critical review using Carnwell \& Daly method in 2021. The study population consisted of scientific sources and texts. In this study, definition and models of Scientific Hegemony were reviewed and critiqued using the Carnwell \& Daly model in 5 stages, which include: determining the purpose of reviewing texts, determining the scope of study, identifying relevant texts, reviewing texts, writing reviews and results Is. Text searches were performed systematically and comprehensively on databases and GOOGLE and ERIC and PUBMED websites.

Results: In the current study, 3 concepts with the most relevance in the field of scientific hegemony were extracted also the results of the study based on 12 proposed layers to evaluate the concept of Scientific Hegemony showed that a superficial and simplistic approach to the category of authority is usually limited to the number of published articles and the number of citations of these articles. Taking a closer look at the countries that have the status of scientific reference in various fields, we find that the advantage of these countries is far beyond just producing articles. In fact, the authority of these countries is the result of decades of investment in cultural, theoretical, philosophical, infrastructural and institutional development in these scientific disciplines.

Conclusion: According to the obtained results, it can be concluded that to achieving comprehensive scientific Hegemony requires a special strategy for each layer of the model. A deeper look at the category of Scientific Hegemony confirms that the Scientific Hegemony that we are currently seeing examples of in some Western countries is the result of more radical and long-term developments that include the philosophical and theoretical levels of scientific development. In other words, achieving the position of Scientific Hegemony requires that universities and academic centers excel in the fields of education, research, technology, theorizing, reference and reliance, accountable, up-to-date, leading, and globally.
\end{abstract}

Keywords: Scientific Hegemony, Higher Education System, Critical Review Method

\section{INTRODUCTION}

Educational centers and universities are dynamic and complex institutions that have more dynamism and complexity if any approach and study of these institutions is the subject of their study. In addition to the importance and complexity of the attitude towards the university, the promotion of organizational knowledge and learning will also be different in terms of the type of management and planning patterns for the university(1). Undoubtedly, with an in-depth and scientific view at new organizations, it can be said that they have changed drastically due to the two concepts of complexity and turmoil Furthermore, they are very different from the past because of the time conditions in which they are located. Therefore, the nature of the current world is based on discrete and fundamental change (2); Dr. Drucker believes that in today's world economy, knowledge as a result of the learning process is not a resource like other sources of production, such as labor, capital and land, However, it is a much more important resource for the present age (3). In fact, Dr. Drucker, using her knowledge and knowledge organization, announced a new type of organization in which the mind dominates rather than the power of the arm(4). And this debate has been going on in the country for several years. And is somehow reflected in the policies of the Cultural Revolution Council, the Ministry of Science, Research and
Technology, and the Ministry of Health and Medical Education. Scientific Hegemony is quite a complex issue that can be had different impressions(5), Most scholars agree that the mere focus on the articles confirms that the Scientific Hegemony that we now see examples of in some Western countries is the result of more radical and longterm developments, Which includes philosophical and theoretical levels of scientific development(6). In the last two decades, due to the efforts of the academic community and despite the lack of facilities and problems, we have seen significant growth in the number of research articles, but this is not all that is necessary for Scientific Hegemony (7). The main purpose of the critical review is to gain insight into the recent state of knowledge in this area and the major questions that need to be answered(8). The resulting model tries to express all the necessary dimensions and components in the scientific Hegemony, the relationship between these dimensions is determined and the relationship between the concept under study and other related concepts is determined. The most important issue in moving towards the production of science and gaining a world-class position is the existence of a uniform image of the concept of Scientific Hegemony in the minds of academic elites. Accordingly, in this study, we explain the multi-layered model of scientific Hegemony. 


\section{METHOD}

This study is a critical review using the Carnwell and Daly method (9), which was conducted. In this study models of Scientific Hegemony will be reviewed and critiqued using the Carnwell and Daly model in the following 5 steps. These 5 steps include: determining the purpose of reviewing texts, determining the Scope under study, identifying relevant texts, reviewing texts, writing a review, and conclusion.

1) Determine the purpose of reviewing texts: Due to the limitations of scientific Hegemony, various views and definitions of concepts related to Scientific Hegemony were first critically reviewed. Then, the limited models existed in this area were reviewed and critiqued based on which approach or theory of model was classified. In this study, our purpose was to review the texts, review the models, approaches and definitions in the field of Scientific Hegemony to finally use them to develop a basic model for Scientific Hegemony in the health education system.

2) Determining the Scope: Both experimental and theoretical research published in research journals and some gray sources (lecture in seminar) in databases were used in the present study. It should be noted that the theories, approaches, perspectives and conceptual frameworks that were in different studies have been given special attention by the researcher. Text searches were performed systematically and comprehensively on databases and GOOGLE, ERIC and PUBMED websites using keywords such as:

Scientific Hegemony - Scientific Authority Philosophical Paradigm - Power - Discipline - knowledge growth - knowledge development

Also, in this stage of the search, OR and AND were used to combine the main concepts.

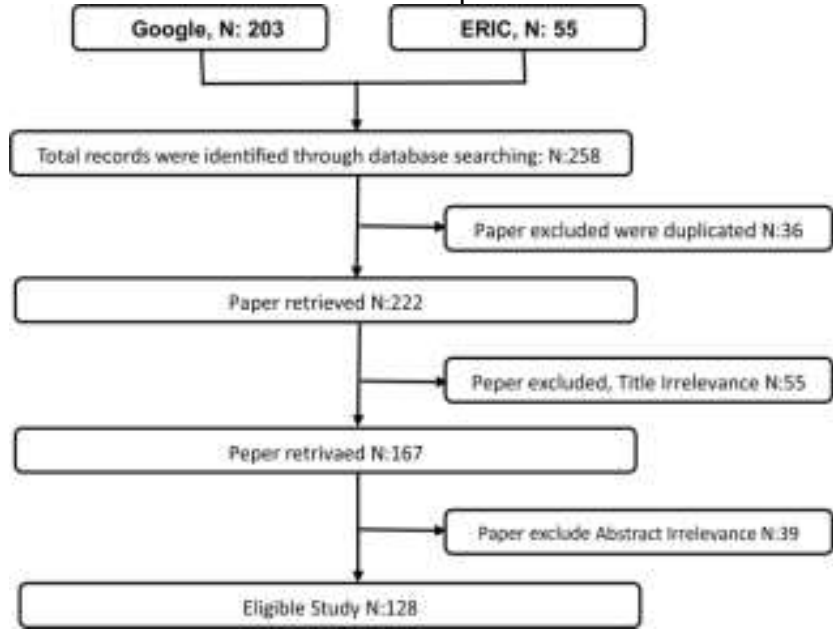

Figure 1. Data Resource Screening Flowchart (First Stage Study)

3) Identify related texts: The views and opinions of all experts in the field of hegemony and scientific development were also studied and analyzed scientifically regarding the novelty of the subject of Scientific Hegemony, the limited models, and theories in this field.

4) Browse texts and Writing a review of texts: At this stage, the researcher superficially reviewed the summary and the main text of the articles in order to understand why and how those studies were conducted and in order to remove sources unrelated to the review of the initial screening topics. Then, a summary of the articles and texts studied and articles that have presented the theory or dimensions and components of Scientific Hegemony or have provided evidence related to theories and models of Scientific Hegemony were selected to read the full text. On the other hand, articles or documents that were in languages other than Persian and English will be deleted at this stage. First, we have used the expression and presentation of theories and views about knowledge and related concepts, power and related concepts, and Scientific Hegemony in the language of theorists. Then, if there were the views of experts on the criticisms, its theories or definitions would be presented. After that, the view and definition of the researcher himself were presented.

5) Conclusion analysis: In this section, two parts are presented. The first part clarifies the concept of scientific hegemony and related concepts. Then, it integrates all the results obtained, which can logically lead to the goal of a new study and conceptual framework. In formulating the conclusion, it is necessary to draw the results from both categories within the main conclusion. Gaps and limitations of previous work should be revealed. Given that at this stage the aim is to provide a prototype that is the result of reviewed and critiqued studies that will be used for the components of the model and the relationships between them. Thus, the conclusion is the initial model of scientific Hegemony. The final product will be a critical review, which will be cited as the initial model throughout the study of this dissertation.

\section{RESULTS}

There are many perplexing concepts in the concept of scientific hegemony. Concepts based on semantic proximity were first examined in order to avoid confusion and ambiguity. Their characteristics were identified by criticizing and comparing the definitions and evidences of each of the concepts. Then, considering the multi-layered model of discipline as a thematic unit in the higher education system, the multi-layered model of scientific hegemony which includes 12 layers are presented with examples.

1) In the first step, the conceptual features of scientific hegemony as well as the adjacent and related concepts are presented.

1-1) Characteristics of scientific growth

Objective: The goal of scientific growth is to increase in size and scientific output. (10)

Examples: Examples of scientific growth are increasing scientific texts, increasing the number of scientific communities, increasing the number of research institutes and increasing science production in the country (10).

Key point: In scientific growth, quantitative and superficial growth takes place in science and it is responsible for the scientific growth of a research discipline $(11,12)$.

\section{1-2) Characteristics of scientific development}

Purpose: The purpose of scientific development; is transformation that takes place through the irreversible density of scientific elements such as knowledge, techniques, knowledge and technique and it caused the 
knowledge and awareness of individuals in society to increase and use knowledge to produce technology $(13,14)$.

Examples: examples of scientific development; Quantitative and qualitative growth of products, services, transformation of quality of life and social fabric of society, income adjustment, eradication of poverty and deprivation, scientific growth and endogenous technology (13).

Key point: Scientific development is a qualitative concept. In addition to the quantitative growth of science, it has been changed in social institutions and attitude and it has been increased the ability to use existing capacities. Moreover, scientists are responsible for the scientific development of a discipline $(11,12)$.

\section{Characteristics of Scientific Hegemony}

Purpose: The purpose of the Scientific Hegemony of the origin of normal science is to be the source of effect in society and to gain a high position in the field of science and technology and to become the center of science production in the world (15).

Examples: Pioneering in the development of knowledge frontiers, having the largest share of activities, processes and knowledge products, using the world of the opinions of thinkers and experts, and establishing an independent scientific structure are examples of Scientific Hegemony (12).

Key points: A form of legitimate soft power that is achieved through hegemony in the fields of science and technology. Additionally science and technology policymakers are responsible for attaining the position of Scientific Hegemony $(16,17)$.

Defining the concept of Scientific Hegemony: Scientific hegemony is a form of legitimate soft power (18) that is achieved through superiority and sovereignty in the fields of science and technology. Pioneering in the development of knowledge frontiers, and having the largest share of knowledge activities, processes, and products in a scientific discipline is a clear example of scientific hegemony. Scientific hegemony means a pivotal influence on the current position and formation of the future status of a scientific discipline. The place of scientific hegemony is the origin of normal Science.

2- Multi-layered model of scientific hegemony: In Dole step, a multi-layered model of Scientific Hegemony based on a multi-layered discipline model (19) is presented. Here we put the model of 12 layers of scientific hegemony and then we define and interpret each of the layers with an example (Figure 2). Also, in this study, by reviewing, integrating and generalizing the different views and definitions of the discipline, a multi-layered model of the scientific discipline is presented. This model includes 13 main layers and 38 sub-layers. Each of these layers identifies one area of the scientific disciplines.

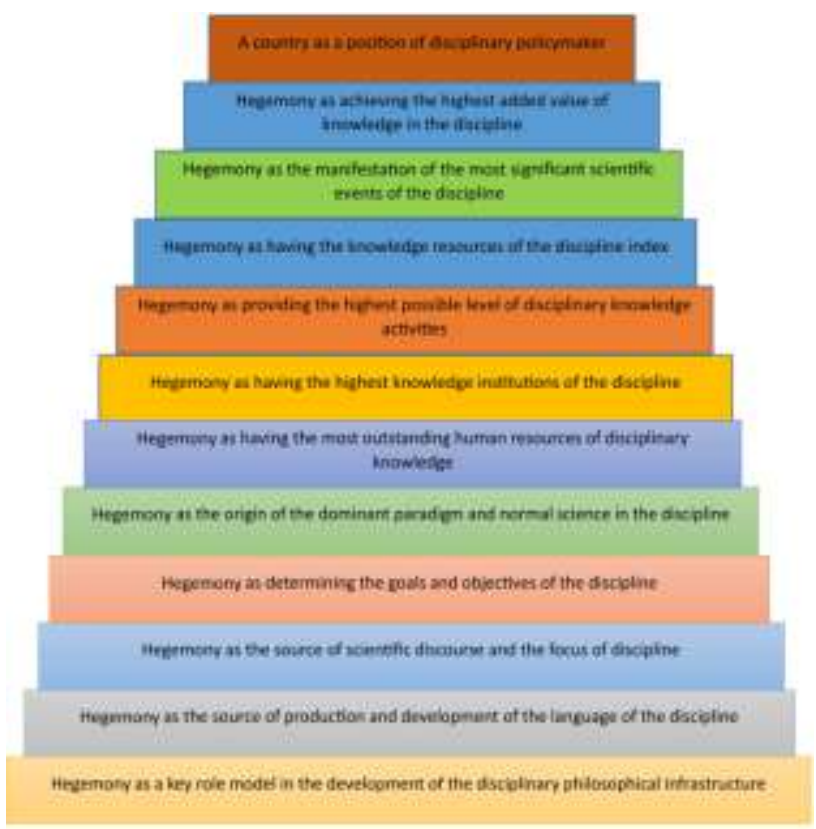

Figure 2. Scientific Hegemony as a multi-layered abstract structure

Scientific Hegemony as a multi-layered abstract structure: A deeper look at the category of Scientific Hegemony confirms that the Scientific Hegemony that we are currently seeing examples of it in some Western countries is the result of more radical and long-term developments that include the philosophical and theoretical levels of scientific development. In other words, achieving the position of Scientific Hegemony requires universities and academic centers excel in the fields of education, research, technology, theorizing, reference and reliance, accountable, up-to-date, leading, and worldwide.

2-1- Hegemony as a key role model in the development of the disciplinary philosophical infrastructure: Hegemony as a key role model in the development of the disciplinary philosophical infrastructure each discipline has its own philosophical foundations. One of the pillars of Hegemony in a discipline is the active participation of the country's thinkers in the development of assumptions and philosophical foundations of that field. In other words, a country that determines the ontological, epistemological, methodological, semantic, and value assumptions of a discipline has acquired the philosophical foundation of that discipline. The following are examples of philosophers who have had the greatest impact on the world of science over a period of 2,500 years (table1). (20) Descriptive results of philosophers based on 500-year periods

Table 1. Absolute abundance of influential philosopher countries in the whole world by time period

\begin{tabular}{|l|l|l|l|l|l|l|l|}
\hline 500 -year courses & 300-year period & $\begin{array}{l}100 \text {-year } \\
\text { period }\end{array}$ & 100 -year period \\
\hline $500 \mathrm{BC}$ & $500 \mathrm{BC}$ & $500 \mathrm{AD}$ & $\begin{array}{l}500 \text { to } 1000 \\
\mathrm{AD}\end{array}$ & $\begin{array}{l}1000 \text { to } 1500 \\
\mathrm{AD}\end{array}$ & 1500 to $1800 \mathrm{AD}$ & $\begin{array}{l}1800 \text { to } 1900 \\
\mathrm{AD}\end{array}$ & 1900 to $2000 \mathrm{AD}$ \\
\hline Greece & Greece & Greece & India & India & England & England & Australia- England \\
\hline China & China & Greece & Iraq & Malaga & England & Denmark & Germany \\
\hline Greece & Greece & Italy & Iran & Italy & France & Germany & France \\
\hline Greece & Greece & India & Iran & Iran & England & England & Germany \\
\hline & Greece & Egypt & & France & Netherlands & Germany & France \\
\hline
\end{tabular}




\begin{tabular}{|c|c|c|c|c|c|c|c|}
\hline & China & Greece & & Spain & Germany & America & America \\
\hline & Greece & Algeria & & China & Italy & Germany & England \\
\hline & Greece & Egypt & & Spain & Ireland & Germany & America \\
\hline & Greece & & & Andalusia & France & Germany & America \\
\hline & China & & & Japan & Scotland & France & America \\
\hline & & & & Italy & Switzerland & America & France \\
\hline & & & & Scotland & Germany & England & America \\
\hline & & & & England & Germany & Italy & Germany \\
\hline & & & & Italy & France & Japan & England \\
\hline & & & & & England & England & France \\
\hline & & & & & Germany & England & America \\
\hline & & & & & Germany & Germany & America \\
\hline & & & & & France & Australia & America \\
\hline & & & & & & Germany & America \\
\hline & & & & & & Germany & Australia \\
\hline Greece 3 & Greece 7 & Greece 3 & Iran 2 & Italy 3 & Germany 5 & Germany 8 & America 9 \\
\hline China1 & China 3 & Egypt 2 & India, Iraq 1 & Spain 2 & France, England 4 & Germany 5 & Germany 3 \\
\hline & & $\begin{array}{l}\text { Italy, India, } \\
\text { Algeria } 1\end{array}$ & & $\begin{array}{l}\text { India, Malaga, } \\
\text { Iran, France, } \\
\text { China, Japan } 1\end{array}$ & $\begin{array}{l}\text { Netherlands, Italy, } \\
\text { Ireland, Scotland, } \\
\text { Switzerland } 1\end{array}$ & $\begin{array}{l}\text { Denmark, } \\
\text { America, } \\
\text { France, Italy, } \\
\text { Japan } 1\end{array}$ & $\begin{array}{l}\text { England } 3 \\
\text { Australia } 2\end{array}$ \\
\hline
\end{tabular}

2-2- Hegemony as the source of production and development of the language of the discipline: $A$ country that has gained the position of Hegemony in a scientific field, builds and manages the language of that field. Development of specialized vocabulary and management of the standard discipline vocabulary system (tree structure or network of words) is one of the examples of specialized discipline language Hegemony.

2-3- Hegemony as the source of scientific discourse and the focus of discipline: A country that claims Hegemony in a scientific field actively participates in and directs the international scientific discourse of that field; identifies the fundamental issues facing the scientific community of the discipline; and it determines the research priorities of the field.

2-4- Hegemony as determining the goals and aims of the discipline: The whole goals and aims of a discipline can be classified into three groups: cognitive aims (for example, in the discipline of medical education, recognition of phenomena such as learning and the development of professional ethics), moral aims (for example, in the discipline of medical education, determining the characteristics of optimal learning and explaining the optimal form of professional ethics), and practical aims (for example, in the discipline of medical education, the development of methods that facilitate and accelerate learning and the formation of professional ethics). The effort of the scientific body of each discipline is ultimately to achieve these aims. The Hegemon country in a discipline has the largest share in determining the end of the discipline.

2-5- Hegemony as the origin of the dominant paradigm and normal science in the discipline: Based on the principle of under determination, one can have countless theories related to a single set of phenomena in each discipline. However, at any given time, only one group of these theories has been favored by the main body of the scientific community of the discipline and it constitutes normal science (21). The Hegemon country in a discipline has the greatest share in choosing the dominant paradigm and shaping normal Science at any point in time.
Table 2. The names of the most effective theories and ideas in the modern world by countries in the period 1500 to 2000

\begin{tabular}{|l|l|l|l|l|}
\hline Row & Country & Number & Percent & Theories and ideas \\
\hline 1 & Germany & 4 & 18 & $\begin{array}{l}\text { Cell, Copernicus, } \\
\text { relativity, technical plate }\end{array}$ \\
\hline 2 & Italy & 3 & 14 & Germs, string, depth \\
\hline 3 & England & 7 & 33 & $\begin{array}{l}\text { Evolution, Atomic } \\
\text { modernity, Gravity, } \\
\text { Geographic time, } \\
\text { Sustainable design, } \\
\text { Utopia, Absolutism }\end{array}$ \\
\hline 4 & France & 2 & 10 & $\begin{array}{l}\text { Social contract, single } \\
\text { art }\end{array}$ \\
\hline 5 & Switzerland & 1 & 5 & Piaget \\
\hline 6 & America & 2 & 10 & Urban Design, Big Bang \\
\hline 7 & Denmark & 1 & 5 & Quantum \\
\hline 8 & Greece & 1 & 5 & Atomic \\
\hline
\end{tabular}

The table above shows that, there are scientists who had effective theories and ideas in the modern world and they caused the formation of normal Science from the United Kingdom (33\%) and Germany (18\%), respectively. Italy were $(14 \%)$, the United States and France (10\%), Switzerland, Denmark and Greece were (5\%) in the period from 1500 to 2000 AD (22).

2-6- Hegemony as having the most outstanding human resources of disciplinary knowledge: The Hegemon country in a scientific discipline can cultivate the most prominent scientists, researchers, and theorists in that field or it attract them from other parts of the world. Talented and knowledge-seeking students are willing to suffer exile to study in the best education and research centers of a field in the reference country.

2-7- Hegemony as having the highest knowledge institutions of the discipline: Leading knowledge institutions and institutes in the world are one of the clear examples of scientific Hegemony. Knowledge institutions include universities, as well as institutions with special capacities for higher education, such as colleges, technical education institutions, colleges, research laboratories, elite centers and distance learning centers, research centers, management centers and knowledge translators.

2-8- Hegemony as providing the highest possible level of disciplinary knowledge activities: Scientific 
Hegemony in a knowledge field requires research (knowledge production), education (knowledge transfer), knowledge management and translation, and the provision of knowledge services (knowledge application) at the highest possible quality level. We must consider that a country that has done more in this area can introduce itself as a Hegemon country.

2-9- Hegemony as having the knowledge resources of the discipline index: The country of Hegemon has a scientific discipline, scientific reference books, and highimpact scientific journals, and databases of scientific articles. Every year, countries around the world publish several books, which increase knowledge, awareness and obedience. The table below (Table 3 ) lists the countries that publish the most books annually. The IPA report released in October 2015 shows of the books released by the 25 biggest book markets, China published $28 \%$ of the total, and the US 20\% (23).

Table 3. Absolute frequency of book printing in different countries of the world

\begin{tabular}{|l|l|l|l|}
\hline Rank & Country & Year & Number of book titles \\
\hline 1 & China & 2015 & 470000 \\
\hline 2 & United States of America & 2015 & 339000 \\
\hline 3 & England & 2015 & 173000 \\
\hline 4 & France & 2015 & 106800 \\
\hline 5 & Germany & 2015 & 89500 \\
\hline
\end{tabular}

2-10- Hegemony as the manifestation of the most significant scientific events of the discipline: One of the examples of scientific Hegemony in a scientific discipline is holding international conferences (seminars and conferences) at the highest scientific level with the participation of world-renowned scientists and scholars. The purpose of holding conferences is to create an atmosphere for the exchange of information and opinions of community members on various scientific and research topics and to create opportunities to examine the community's reactions to that topic and to create social developments. Conferences are directly related to the growth and development of a society.

2-11-Hegemony as achieving the highest added value of knowledge in the discipline: The development of knowledge-based economy, the formation of a special technology innovation system and the establishment of knowledge-based centers with the aim of creating economic and non-economic added value is one of the most important manifestations of scientific hegemony in a discipline. The Organization for Economic Co-operation and Development (OECD) defined the term knowledgebased economy in 1996 as an economy that is directly based on the production, distribution, use of knowledge and information.

2-12-Hegemony as country as a position of disciplinary policymaker: A country that acquires the position of scientific hegemony in a scientific field usually hosts institutions that work internationally in the field of policymaking, setting standards, evaluation and accreditation. For example, each organizations and institutions mentioned below play the role of hegemony in the development of standards, accreditation, and etc. in the field of medicine as a position of disciplinary Hegemony.

World Health Organization: It is one of the specialized agencies of the United Nations, which plays the role of an organizing Hegemony on the health of the world community (24).

World Federation of Medical Education: An NGO founded in Copenhagen. Its founding organizations included the World Health Organization and the World Medical Association. The organization is currently registered in the UK and France (25).

Foundation for Advancement of International Medical Education and Research: Promotes excellence in the teaching of international health professions through programming and research activities(26).

Accreditation Council for Graduate Medical Education: The council was established in 1981 and was preceded by the Communications Committee for Graduate Medical Education, established in 1972. The council currently oversees graduate education for all MD and DO (Osteoporosis) physicians in the United States (27).

The Liaison Committee on Medical Education: Is a reputable institution for educational programs in medical schools in the United States and Canada. It is sponsored by the American Medical Association and the American Medical Association (28).

\section{DISCUSSION}

The strategy of Scientific Hegemony is the result of a series of strategic and long-term decisions of the country in the national horizon and in the level of higher education, which is expected as a result of integrating policies ,macro policies and the realization of the vision document and finally providing Scientific Hegemony to the title of a continuous collection (4). A country that acquires the status of a Scientific Hegemony in a scientific field usually hosts institutions that work internationally in policy-making, lawmaking, standardization, evaluation, and accreditation. For example, the organizations and institutions mentioned above each play the role of Hegemony in the development of standards, accreditation, etc. in the field of medicine $(23,24,25,26,27$,$) . The level of benefit of science and$ knowledge in a society determines the value and position of that society (29). The purpose of this study is to clarify and design a conceptual model of Scientific Hegemony in the higher education system. Regarding the first layer of Hegemony as a key role in the development of the philosophical foundation of the discipline, Mr. Duyigan (2010) examined and researched the most influential philosophers who were advanced in the assumptions of ontology, epistemology, and axiology. Initially, ontological philosophers attributed human existence to the natural elements earth, air, fire, and water. Other philosophers claimed that the basis of everything is not elements, but mathematics. St. Augustine (354-430 AD) claimed that only through thought and communication with God can humans find true happiness (20). In the case of the second layer, the International Institute of Medical Education was first to attempt to create a glossary and Thesaurus. In 2002, the institute created a linear word meaning in the form of an alphabetical list. These words do not have a thesaurus or taxonomic form. In the early 1980s, the world's first medical education thesaurus was built by the Ninewells Medical Library in Dundee, Scotland, followed by an international project (METRO) which is still ongoing and it is building a huge international medical education thesaurus (30). These 
are just some of the goal setting shareware that you can use Regarding the third layer, Mark Tomlinson in his article "Overview of the process of setting research priorities at the national level in low- and middle-income countries" stated that although more than 130 billion dollars need annually in the field of capital health research to prioritize health research investment in a fair and legitimate manner, using a sound and transparent methodology is evident. Observed real priorities indicated that there was not a regular and operational application process for the identified priorities in the countries (31). This was the only clear example that can be given in this section. In the case of the fourth and fifth layers, the French chemist Louis Pasteur took this concept one step further and developed vaccine to prevent the spread of diseases such as cholera, anthrax and rabies. In this way, cell theory and microbial theory saved millions of lives. Other biological sciences focused on the subject of diversity. The theory of the evolution of growth and development depicted life from simple to complex in motion. Evolution distinguishes between different species (22). These cases were one of the examples presented in this section. Regarding the sixth layer, recent data from the Atlas Project International Educational Institute in 2018 show that there are 16 major host countries for international students: The United States, Canada, the United Kingdom, Australia, Germany, France, Japan, and New Zealand. He cited China, Mexico, the Netherlands, Spain, Sweden, Russia, Finland and India as examples (32). This example was very striking in this part. In the case of the seventh layer, numerous studies in the rankings of institutions, both research centers and academies in the coming years, exemplified Iran's higher education, which has a growing trend in terms of quantity, according to the Global Innovation Index. Iran has increased from 24 to 2 in terms of higher education (number of universities) from 2012 to 2019 (33). Regarding the eighth, ninth, tenth, eleventh and twelfth layers, it can be said that these layers are one of the examples of scientific hegemony in a very important scientific discipline, which represent the International conferences, science production and reference books, respectively. Moreover, Scientific is the scientific hegemony in a scientific discipline, the development of knowledge-based economy, the formation of a special technological innovation system and scientific hegemony in a scientific field.

\section{CONCLUSION}

There are many ambiguities about concept of scientific hegemony in the world. In this study, in general, critique and comparison of definitions and evidence of each of the concepts, their characteristics were identified. Also, a multilayered model of scientific hegemony that includes 12 layers was based on the multi-layered model of discipline as a thematic unit in the higher education system with examples presented. Scientific growth in higher education institutions, scientific texts, the number of scientific communities, the number of research institutes and science production in the country can be increased based on these layers presented in this study. According to the results of the study, changing in quality of life and social fabric of society, income adjustment, poverty and deprivation and endogenous technology can be observed with scientific development, quantitative and qualitative growth of products and services. In general, it can be said that Scientific Hegemony is a form of legitimate soft power that is achieved through superiority and sovereignty in the fields of science and technology. In the end, it can be concluded that the most important issue in achieving scientific hegemony and achieving global excellence is initially the same understanding of policymakers and elites of the higher education system of the concept of scientific hegemony as well as strategic planning in cultural, philosophical, theoretical, institutional and it is the infrastructure of scientific disciplines.

\section{REFERENCES}

1. Moghadam $M H$, Heidarzadeh $A$, Bashiri $H$, Khoshrang $H$, Dadgaran I. Scientific excellency model in Iran's higher education case study: Guilan university of medical sciences. foresight. 2020.

2. Pourabbasi A, Akbari H, Akhvan AA, Haghdoost AA, Kheiry Z, Dehnavieh R, et al. Analysis of Iran's National Medical Education Evolution and innovation plan using the Michelle and Scott's model of policymaking. Journal of Advances in Medical Education \& Professionalism. 2019;7(1):20.

3. Hasani K, Sheikhesmaeili S. Knowledge management and employee empowerment: A study of higher education institutions. Kybernetes. 2016

4. Sułkowski Ł, Fijałkowska J, Dzimińska M. Mergers in higher education institutions: a proposal of a novel conceptual model. Managerial Finance. 2019.

5. Mehlenbacher B, Bennett L, Bird T, Ivey M, Lucas J, Morton $\mathrm{J}$, et al., editors. Usable e-learning: A conceptual model for evaluation and design. Proceedings of $\mathrm{HCl}$ International; 2005.

6. Haddist K, Handayani NU. A Conceptual Model for Analysis the Role of Knowledge Management in Organizational Performance in the Quality Assurance of the Higher Education. Proceedings of the First IEOM Global Engineering Education Conference. Atlanta, Georgia, USA, 2020.

7. Jones SR, Torres V, Arminio J. Negotiating the complexities of qualitative research in higher education: Fundamental elements and issues: Routledge; 2013.

8. Mirmoghtadaie Z, Ahmady S, Yazdani S, Mojtahedzadeh R, Afshar L. Professional practice of medical training in the elearning system: the conceptual model based on a critical review. Journal of Medical Education. 2016;15(4):214-20.

9. Carnwell R, Daly W. Strategies for the construction of a critical review of the literature. Nurse education in practice. 2001:1 2:57-63.

10. Shababi H, Yahyazadehfar M, Rasekhi S, Shirkhodaie M. Determining the Relationship among Science Development, Technology Development and Economic Growth in Iran using DANP. Journal of Technology Development Management. 2018;5(4):105-42.

11. Tavassoli Gh. Comprehensiveness of the concept of development and its relationship with culture. Development culture. 1994 (15): -

12. Shahin A,Mahbod MA. Managing the process of drawing a comprehensive scientific map of the country: a systematic and balanced approach to the scientific disciplines of universities. National Congress of Humanities; 2006.

13. Azkia M. Sociology of Rural Development and Underdevelopment in Iran. Tehran: Information; 1999.

14. Movasaghi A. War and underdevelopment in the Third World. Politics - Journal of the Faculty of Law and Political Science. 2009; 39 (2)

15. Fayaz E. The role and position of the educational system in the process of scientific authority of the country. The first national conference on education in Iran 1404 
16. EaM L., Chantal. Hegemony and Socialist Strategy: Towards a Radical Democratic Politics. : ; . London: Verso; 1985.

17. Goodarzi Gh, Roudi K. Interpretation of Scientific Authority for Educational institutions by Applying Grounded Theory. journal science \& technology policy. 2011. Volume 4, Issue 2.75-90

18. Johnston JL. When I say ... hegemony. Med Educ. 2017 Aug;51(8):782-783. doi: $10.1111 /$ medu.13235. Epub 2017 Feb 6. PMID: 28168726.

19. Yazdani S, Hajiahmadi M, Shakerian S. Rethinking interdisciplinarity: Proposing a multilayered model. Medical Journal of the Islamic Republic Of Iran. 2020;34(1):802-10.

20. Duignan B. The 100 Most Influential Philosophers of All Time: Britannica Educational Pub. In Association with Rosen Educational Services; 2010.

21. Kuhn TS. The structure of scientific revolutions 1970.

22. Abend G. The Meaning of 'Theory'. Sociological Theory. 2008;26(2):173-99.

23. Ha T-H. China and the US make nearly half the world's books August 18, 2017 [Available from: https://qz.com/1057240/.

24. World Health Organisation 2020. Available from: https://www.who.int/about

25. World Federation for Medical Education 2020. Available from: https://wfme.org ./

26. Foundation for Advancement of International, Medical Education and Research 2020 [cited 2020]. Available from: https://www.who.int/workforcealliance/members partners/me mber_list/faimer/en /

27. Accreditation Council for Graduate Medical Education 2020. Available http://www.acgme.org/acWebsite/home/home.asp .

28. "Directory of Accredited Programs". LCME. 2020

29. Zhang J, Sun Y. Development of a conceptual model for understanding professional learning communities in China: a mixed-method study. Asia pacific education review.2018;19(4):445-57.

30. Haig A, Ellaway R, Dozier M, Liu D, McKendree J. METRO-the creation of a taxonomy for medical education. Health Info Libr J. 2004 Dec;21(4):211-9. doi: 10.1111/j.14711842.2004.00534.x. PMID: 15606878.

31. Tomlinson, $M$ \& Chopra, M .A review of selected research priority setting processes at national level in low and middle income countries: Towards fair and legitimate priority setting. Health research policy and systems / BioMed Central. (2011). 9. 19. doi: $10.1186 / 1478-4505-9-19$

32. Atlas Project. Top host distination 2018. Available from: www.iie.org/projectatlas

33. Dutta S LB, Wunsch-Vincent S.: Winning with global innovation. The Global Innovation Index: 2016; 